\title{
An overview of shark fisheries in Kupang, East Nusa Tenggara Province, Indonesia
}

\author{
$S$ P S Dewi ${ }^{1 *}, O$ S Abdoellah ${ }^{2}$ and $Y \mathrm{~N}$ Ihsan $^{3}$ \\ ${ }^{1}$ Environment Science Program, Postgraduate School, Universitas Padjadjaran, Indonesia \\ ${ }^{2}$ Center for Environment and Sustainability Science, Universitas Padjadjaran, Indonesia \\ ${ }^{3}$ Faculty of Fisheries and Marine Science, Universitas Padjadjaran, Indonesia
}

\begin{abstract}
The biology of sharks makes them very vulnerable to fishing pressure. Globally, sharks are threatened because of uncontrolled fishing due to the increasing demand for their fins. In Indonesia, shark fishing occurs in almost all marine areas, and each area has different characteristics and conditions. Understanding the conditions and characteristics of each area will help to define strategies for the sustainable management of shark fisheries. This paper aimed to provide an overview of the condition of shark fisheries in Kupang, East Nusa Tenggara, Indonesia. This study used a qualitative method to get information about fishing techniques, catch composition, utilization, and trading. The data were collected through observation, interviews, and literature review. The result showed that fishermen in Kupang caught sharks as a fishing target using longline fishing gear. Almost all sharks were landed in pieces after being chopped up in the vessel. They were chopped off into some pieces, such as the fin, meat, skin, and cartilage. Sharks species could be identified by their fins, but their total length, weight, sex ratio, and adult size were difficult to identify. That makes it difficult to plan reasonable management strategies. Shark fins are more expensive than other parts, and the price depends on the fin size. Shark products are traded to Surabaya, Manado, Bogor, and Jakarta. Trade of shark products is regulated by the Minister of Marine Affairs and Fisheries Regulation number 61/PERMEN-KP/2018. Based on this study, management intervention must be undertaken to ensure sustainable shark fisheries in Kupang.
\end{abstract}

\section{Introduction}

Shark belongs to a group of cartilaginous fish and the Chondrichthyes class with the Elasmobranchii subclass. More than 500 species of sharks are found in the seawater around the world, and 117 of those are found in Indonesian seawater [1]. Based on their biological characteristics, sharks tend to have a slow growth rate, long life span, low fecundity, and are slow to reach sexual maturity as well as reproductive cycle [2]. Therefore, sharks are relatively vulnerable to overexploitation.

As a predator in the ocean food chain, sharks play an important role in maintaining the balance of the ecosystem. The loss of apex species which have an important role in the arrangement of the food chain can cause very dramatic ecological changes [3]. Uncontrolled fishing activities will cause a threat of shark extinction in the world. Therefore, management efforts are needed so that shark resources remain sustainable.

Globally, the existence of sharks is currently threatened with extinction due to overfishing caused by the increasing world demand for shark commodities, especially their fins. There are $15 \%$ of shark species of the world are threatened due to overfishing [4]. At least,
100 million sharks are killed each year, exceeding the average recovery potential of most sharks [5]. In Indonesia, initially, shark fisheries were not as popular as other fishery commodities. However, since 1988, when the price of shark fins in the world market increased, shark fisheries business has grown quite rapidly. Some fishermen in several fishing centers in Indonesia make sharks as their main catch or target [6]. In 1998-2015 period, Indonesia was recorded as the largest fishing country for shark species in the world with an average catch of $112,472.6$ tons or $14 \%$ of the world's catch [7].

Shark fishing occurs in almost all Indonesian territorial waters. Indonesia has a large sea area and many fish landing sites have different facilities, characteristics, and conditions. Therefore, shark fisheries management strategies must be adapted to the conditions of each area. However, shark research in Indonesia is still focused on Tanjung Luar, West Nusa Tenggara. Not many studies have explored the eastern part of Indonesia, such as in Kupang, East Nusa Tenggara. There were 95 times of shark distribution products from Kupang during 2017 with a total of 79.49 tonnes to several regions in Indonesia, such as Surabaya and Jakarta which were then used as export commodities, especially shark fin products [8]. This

\footnotetext{
*Corresponding author: spratiwi.unpad@gmail.com
} 
study aimed to provide an overview of the shark fisheries in that location. Information on shark fisheries in Kupang, East Nusa Tenggara enables to inform better conservation and management of shark fisheries in Indonesia, especially at the local level.

\section{Methods}

This study used a qualitative approach to obtain information related to fishing activities, catch composition, utilization, and trade. Data collection was carried out in Kupang in September 2020 through observation, interviews, and literature study. Interviews were conducted with key informants who were determined by purposive sampling with the consideration that they were concerned about shark fisheries, had more than five years of experience, knew and understood about shark fishing activities, were willing to be respondents, and could communicate well. The informants were shark fishermen, shark traders, and government agencies (BPSPL Denpasar Wilker NTT). Secondary data were obtained from the results of previous researches and reports from government agencies BPSPL Denpasar Wilker NTT, and Stasiun PSDKP Kupang.

\section{Result and Discussion}

\subsection{Fishing Activities}

In Kupang, sharks are the fishing target of several fishermen based in Namosain. Sharks were caught by 619 GT vessels using longline fishing gear; the types of vessels and gears are presented in Figure 1 and 2. The fishing ground was located in Timor Sea-WPP 573. One vessel unit usually involved 5-6 fishers. The duration of a fishing trip in the sea was around 12-14 days. They managed to catch about 10-30 sharks per day, and reached about 150-200 sharks in one trip, depending on the weather. Calm waves and winds are good conditions to catch sharks. The catching season usually starts from March to November with a peak in September.

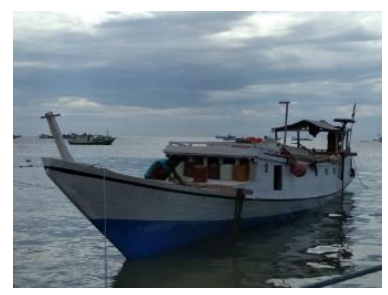

Fig.1. Namosain fishing boat

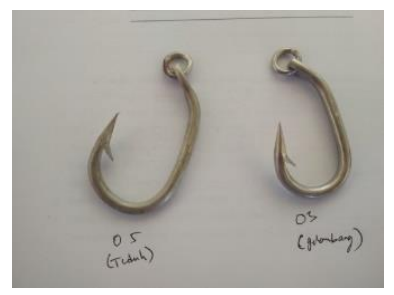

Fig.2. Fishing hooks of shark longline used by Namosain fishers
However, during the Covid-19 pandemic in 2020, from March to July, there were only four fishing trip noted to catch sharks and started to increase again in August. There were 16 fishing trip recorded during August-September. The decline in the fishing effort did not only occur in shark fishery, but also gave an impact on others. This occurred due to a decrease in demand for fish products from abroad and domestically.
Sharks were caught and immediately chopped off into pieces on the vessel. The fins, meat, skin, and bones were parted. They were dried under the sun, while the fillet meat was soaked with saline water, then dried under the sun too. This practice was carried out by all Namosain fishermen. Therefore, when the sharks were landed, it was difficult to collect the data on species and biological traits, such as body length, weight, adult size, and sex. This made it difficult to evaluate population status and determine the total allowable catch. Lack of information regarding the data of catch, potential, species diversity, biology, levels of exploitation, and institutional socio-economic resources of sharks and rays in Indonesia is an obstacle in determining the rational basis for implementing sustainable management of shark and ray fisheries [6].

\subsection{Catch Composition}

Even though the sharks were landed partially, it was possible to collect data on species and the total number of catches. The data collection was carried out on landed dorsal fins, assuming the number of dorsal fins was the same as the number of sharks caught. Shark species identification was done by matching the fins with shark identification books.

Based on a report of shark landing monitored by BPSPL Denpasar Wilker NTT in April-December 2018, there were 16,065 sharks landed in Namosain, Kupang. Twenty-three species were dominated by pelagic and semi-pelagic sharks, such as Carcharhinus limbatus, C. sorrah, and Sphyrna spp. Globally, these shark species are almost threatened to critically endangered in wild. Therefore, the management of shark fisheries must be done by considering the role of sharks in maintaining the balance of the ecosystem. The shark catch composition is presented in Table 1.

Table 1. Composition of Shark Catches

\begin{tabular}{|c|c|c|c|c|c|}
\hline \multirow{2}{*}{ Eamili } & \multirow{2}{*}{ Species } & \multicolumn{2}{|c|}{ Total number } & \multicolumn{2}{|c|}{ Conservation status } \\
\hline & & Sum (Indy) & $\%$ & IUCN & CITES \\
\hline Alopidae & Alopias $5 p$ & 2 & 0.00 & $\mathrm{VU}-\mathrm{EN}$ & App. II \\
\hline \multirow[t]{16}{*}{ Carcharhinidae } & Carcharhimus albimarginatus. & 172 & 1.07 & $\mathrm{vU}$ & \\
\hline & Carcharhimus amblyzhuvashers & 660 & 4.11 & NT & - \\
\hline & Carcharhimus brexipinng & 596 & 3.71 & NT & - \\
\hline & Carch har himus falchiformis & 860 & 5.35 & VU & App. II \\
\hline & Carcharhinus leucas & 108 & 0.67 & NT & - \\
\hline & Carcharhimus Limbatus & 5811 & 36.17 & NT & - \\
\hline & Carcharhimus melanopterus. & 34 & 0.21 & NT & - \\
\hline & Carcharhimus obscurus & 218 & 1.36 & EN & - \\
\hline & Carchar himus plumbens. & 559 & 3.48 & $\mathrm{VU}$ & - \\
\hline & Carcharhimus sealei, & 19 & 0.12 & NT & - \\
\hline & Carcharhimus signatus & 7 & 0.04 & VU & - \\
\hline & Carcharhimus sorrah & 3495 & 21.76 & NT & - \\
\hline & Galeocerdo cuxier & 440 & 2.74 & NT & - \\
\hline & Negaprien acutidens & 57 & 0.35 & VU & - \\
\hline & Prionace glauca & 11 & 0.07 & NT & - \\
\hline & Iriaenodon obesus & 36 & 0.22 & NT & - \\
\hline Hemigaleidar & Hemipristis elongeto & 53 & 0.33 & VU & - \\
\hline & Iswroks, sR & 10 & 0.06 & EN & App. II \\
\hline \multirow{6}{*}{ Sphyrnidae } & Eusphorra blechii, & 54 & 0.34 & EN & 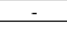 \\
\hline & Sphyrna lewini, & \multirow{3}{*}{2351} & \multirow{3}{*}{14.63} & $\mathrm{CR}$ & \multirow{3}{*}{ App. II } \\
\hline & Sphyrna mokarran & & & $\mathrm{VU}$ & \\
\hline & Sphyrna zyzaena & & & $\mathrm{VU}$ & \\
\hline & Unidentified & 512 & 3.19 & - & - \\
\hline & TOTAL & 16065 & 100 & & \\
\hline
\end{tabular}

\subsection{Utilization and Trading}

The utilization of sharks includes fins, meat, skin, cartilage, and 'tongkat' (upper tail). Almost all of these parts have economic value, with shark fins hold the highest price. Shark fin is the main ingredient for shark fin soup. The dish is often served during Chinese New 
Year celebrations, at weddings, and for banquets when extended families gather. The dish is considered a luxury dish and a symbol of social status.

Fin products are usually dried and sold to traders in Kupang. After that, they are distributed to large traders in Surabaya and Manado. Shark fins are priced based on their size. Usually, shark fins with the smallest size (10 up) are sold for 100,000 IDR per kg and the largest size (50 up) reaches 1.4 million IDR per $\mathrm{kg}$. However, based on the interviews with fishermen and traders, the price of fins during the Covid-19 pandemic decreased due to reduced demand from consumers in Hong Kong and China. Currently, the price of 45 up shark fins, which is usually priced at 1.1 million IDR, has dropped to 900,000 IDR.

Shark meat is also used and sold to traders in Kupang, and the traders sell it to Bogor and Jakarta. In general, shark meat is chopped off into small pieces, parted from the skin, soaked in saline water, then dried under the sun. This process is carried out on the vessel while sailing. The price of this product ranges from 13,000-15,000 IDR per kilogram.

Generally, fishermen will sell all of their catches to traders. Then the traders will sell them according to market needs. Shark fins are usually distributed using air transportation (plane). While, the other products are usually accumulated first until reaching a sufficient number. After that, they will be distributed using sea transportation.

\subsection{Management Challenges}

Several shark species traded are included in Appendix II of CITES. Therefore, their use must be regulated to ensure the sustainability of those shark species. As a country that has ratified CITES, Indonesia is required to regulate the utilization and trade of species included in the CITES Appendix. Follow up on it, the Ministry of Marine Affairs and Fisheries has set the rule with Regulation Number 61/PER-MENKP/2018 concerning The Utilization of Protected Fish Species and/or Fish Species Listed in the CITES Appendix.

Regulating the use of biota is usually carried out through the application of quotas and the determination of these quotas requires a scientific study of the resource condition in each region. Looking at the characteristics of fisheries in Kupang, the main challenge in implementing sustainable shark fisheries management is the provision of shark fisheries data. Incomplete landings make it difficult to provide data on the composition of species and the number of individuals. It is also impossible to identify the sharks caught, whether they are young or adult sharks. Therefore, involving fishermen as enumerators to obtain the required data can be considered. Formerly, researchers had done this action while obtaining data in Papela, Osi, and Dobo [9], places that share similar characteristics to Kupang. Logbooks for shark fisheries can be modified to include the required data for sustainable management.

As a resource, sharks have provided income to some fishermen in Kupang, but with their biological characteristics that are vulnerable to overfishing, policies in their management must be taken carefully.
As a result, the sustainability of shark resources will be maintained and will not result in a major impact on the socio-economic communities who depend on these resources.

\section{Conclusion}

The main obstacle faced in managing shark resources in Kupang was the post-capture handling technique, whereby the caught sharks were directly chopped off into pieces on the boat so that it was difficult to collect data when they were landed. That makes it difficult to plan reasonable management strategies. Therefore, the first thing to do is improving data on shark fisheries. Due to the difficulty of providing data on shark fisheries, it is necessary to involve fishermen as enumerators to obtain biological data on sharks. The fisheries logbook for catching sharks should be modified to include the data required for sustainable management.

\section{References}

1. D. Sadili, Dharmadi, Fahmi, Sarmintohadi, I. Ramli, \& Sudarsono, Rencana aksi nasional (RAN) konservasi dan pengelolaan hiu dan pari 2016 - 2020, KKP, Jakarta, (2015)

2. J.D. Stevens, R. Bonfil, N.K. Dulvy, P.A. Walker, ICES Journal of Marine Science 57, 476 (2000).

3. A. Myers, J.K. Baum, T.D. Shepherd, S.P. Powers, C.H. Peterson, ScienceMag 315, 1849 (2007)

4. N.K. Dulvy, S.L Fowler, J.A. Musick, R.D. Cavanagh, P.M. Kyne, L.R. Harrison, J.K. Carlson, L.N.K. Davidson, S.V. Fordham, M.P. Francis, C.M. Pollock, C.A. Simpfendorfer, G.H. Burgess, K.E. Carpenter, L.J.V. Compagno, D.A. Ebert, C. Gibson, M.R. Heupel, S.R. Livingstone, J.C. Sanciangco, J.D. Stevens, S. Valenti, W.T. White, eLIFE 3, 5 (2014)

5. B. Worm, B. Davis, L. Kettemer, C.A. WardPaige, D. Chapman, M.R. Heithaus, S.T. Kessel, S. H. Gruber, Marine Policy 40, 194 (2013)

6. Fahmi, Dharmadi, Tinjauan status perikanan hiu dan upaya konservasinya di Indonesia (KKP, Jakarta, (2013)

7. D. Derian, F.D. Cahyo, Prosiding SIPP Jilid 2, 917 (2017)

8. Y.K. Pumpun, S.P.S. Dewi, R. Lasniroha, Z. Abidin, S. Wardono, Prosiding Simposium Nas. Hiu dan Pari Indonesia Ke 2, 27 (2018)

9. V.G. Jaiteh, A.R. Hordyk, M. Braccini, C. Warren, N.R. Loneragan. ICES Journal of Marine Science 74(1), 242 (2018) 